Andrzej Lisowski

\title{
NATURAL DISASTERS: FROM HUMILITY IN THE FACE OF DESTINY TO RISK ACCEPTANCE
}

A natural disaster means large losses and damages arising due to occurrence of natural hazard. Most often the numbers of the dead and the injured persons are considered, along with the value of material damages, and the numbers of people suffering in material and psychological terms. During the last half a century there were three natural disasters in Poland which, in the light of the data available, can be considered large on the international scale. Thus, direct material damages amounting to more than $1 \%$ of the GNP were suffered during the floods of $1980(1.6 \%)$ and $1997(3 \%)$, and the snowy winter of $1978 / 79(3.7 \%)$. In none of these events the threshold of 100 dead was exceeded (54 dead in 1997), but more than $1 \%$ of Poles had satisfaction of their everyday needs disturbed ( $1 / 3$ of the country's area was hardly accessible in January and February of 1979, 152 thousand people were evacuated from flooded areas in 1997).

The volume of damages depends not only on the intensity and duration of the extreme natural phenomena, but also on the vulnerability of the society to the effects of hazards, that is - primarily the capability of people to react properly to natural threats. This vulnerability has been dependent in the history of mankind on numerous factors: knowledge on the origins of the extreme geophysical phenomena, prevention and compensation means being at disposal, effectiveness of the protection systems, social position of the potential victims, attitudes to the hazards, as well as the hierarchy of goals valid currently in the social and economic policies of a given society.

\section{FROM HUMILITY IN THE FACE OF DESTINY TO THE GUARANTEES OF SAFETY}

The extreme geophysical phenomena, side by side with the epidemic diseases, famine, and organised violence, have been inciting social emotions for thousands of years, since each of these phenomena resulted first of all in a high death toll. The effects were more important for people than the origins of these phenomena. That is why war also gained the name of a calamity (elementary catastrophe), because it appeared a similarly uncontrollable process as the manifestations of the forces of nature (Bujak, 1932). Such an 
integrated perspective was also the result of acceptance of the most primitive determinism, assuming creation of these phenomena by the supernatural beings, who were penalising sinful men. In the initial period of development of modern natural sciences the calamities were still considered as "natural" factors regulating the population numbers (Botero, Macchiavelli, Malthus).

Human vulnerability to natural hazards was strictly associated with the manner of satisfying the need of security of the society. Irrespective of the attempts undertaken since the beginning of humanity, aimed at counteracting the potential damages, this sphere of the human need of safety had been for a long time dependent only on fate. It was only in the industrial society that the scientific and technological advance allowed to place the need of safety on a high rank in the hierarchy of human needs. A complete reversal of the situation occurred: humility in the face of adversities was replaced by the developing conviction of the possibility of minimising the damages and losses owing to knowledge, technology and organisation. Thus, in the industrial society, in the peak period of the growth of the functions of the state, in the middle of the $20^{\text {th }}$ century, the state became also the underwriter of the safety guarantee. Even in the fortress of liberalism, the United States of America, the share of the federal authorities in compensation of damages and losses increased from $1 \%$ in 1953 to $70 \%$ in the $1970 \mathrm{~s}$.

Limitation of vulnerability to natural catastrophes may take place through organisation of the protection system encompassing: monitoring and forecasting of hazards, warning of the societies in danger, construction of protective facilities, introduction of appropriate principles of land use, as well as construction regulations, provision of an immediate alleviation and preparation of means for compensation of losses. Organisation of such a system of protection required significant material and financial means and adequate co-ordination, which could only be secured by the state. Notwithstanding the obvious advantages of such an undertaking, when the economic benefits from the state rule were put to doubt in the 1970 s, the critical voices with respect to such a safety umbrella appeared as well. An essential role in this case was played, as well, by the reinterpretation of the relation nature man, consisting in the passage from the perspective nature - technology man to the perspective man - technology - nature - technology - man. This reinterpretation consisted in the adoption of the assumption on the interactive character of the consequences of natural hazards. In accordance with this new concept, human communities function in conditions of definite threats in their environment, but their potential negative effects can be amplified by own activity of those communities, which may also lead to quite new threats, previously not existing (Beck, 1992; Zacher, 1994). The low cost effectiveness of the centralised protection systems was indicated, along with numerous organisational shortcomings, actual separation of the decisionmakers from those directly affected, that is - the potential victims, and the improper conceptions as to their attitude with respect to the hazards. 


\section{INEFFECTIVENESS OF THE CENTRALISED PROTECTION SYSTEM}

The technocratic approach to prevention of the natural disasters assumed that the damages are a function of the intensity and duration of the extreme natural phenomena, and the better forecasting of the extreme phenomena, appropriate technical security facilities, as well as specialised services will limit the potential losses to minimum already in the "closest future" (Hewitt, 1983). It turned out, though, at the end of the $20^{\text {th }}$ century, that exceeding a definite scale of technical safeguarding undertakings (like in the case of river regulation), may increase vulnerability to damages (e.g. the floods in Western Europe in the 90s), while, in turn, the efforts aiming at controlling the natural process of exceptional intensity are usually pointless, as demonstrated by the floods in the USA in 1993 and in Poland in 1997.

Organisation of a protection system and ensuring its proper functioning requires significant material and financial means, and so the longer periods free of dangers encourage to making of the not always justified economies (e.g. at the beginning of 70 s the period of mild winters weakened the preventive activities in Poland). Such an apparent safety may protect from inconveniences, but increases vulnerability to damages during the real catastrophes as it took place in January of 1979. In Poland the average delay of longdistance passenger train was almost 3 times longer ( $71 \mathrm{~min}$ ) in January and February of 1979 than the average delay of trains for the years 1960-1990 in these months. Implementation of the protection programmes through excessively bureaucratised institutions raises the costs. In the winter season of 1979/80 the costs of road maintenance were not much lower than a year before. Simply the responsible decision-makers were afraid of the criticism of politicians and communities, who had reproached them after disaster of 1978/79. The centralised protection systems can also hardly be changed, although the reports elaborated after the natural disasters always indicate definite shortcomings in them (Informacja..., 1998).

Protection programmes often concentrate on securing an effective functioning of the fundamental infrastructure of regional and national reach, treating marginally the question of adaptation of the local societies to life in conditions of a hazard. Even the adequately early warning may turn out useless in the situation of lack of the properly drilled behaviours, incapacity of the respective services, and the excessive trust of the inhabitants in the technical safeguards alone. The paternalistic method of protection discourages the population from undertaking the individual preventive measures, since the hazardous events are considered to be exceptional phenomena, requiring the intervention of the specialised institutions, and, on the top, the state guarantees compensation of the losses. The decision-makers mistakenly assume full acceptance of the prevention activities. The problem is constituted by the refusals to evacuate or delaying of evacuation for fear of losing the lifelong-earned material possessions (like in Poland during the floods of 1979 or 1982). Cases are known of not informing the potential 
future victims of the scale of the threat so as to prevent a panic (e.g. victims of flush flood in south-eastern Poland in 1987). The centralised protection systems proved, however, quite effective in the domain of protection of life of the inhabitants. Thus, in the USA the number of deaths caused by hurricanes decreased during the $20^{\text {th }}$ century by $75 \%$. In Poland the flood of 1997 was an exception (54 dead), since during 30 years (1960-1990) altogether 21 persons lost their lives during floods.

\section{ATTITUDES OF THE POPULATION WITH RESPEC'T TO HAZARDS}

Already in the middle of the century the opinion started to become frequent that the reasons of a low effectiveness of the common flood protection measures reside in the attitudes with respect to the hazards. At the beginning, the conditioning for the differentiated attitudes of the population in this domain was assumed to reside - in accordance with the technocratic model of the interaction between man and nature - in the perception of the very threats and own experience of the population. The studies initiated by G.F. White showed that people are extraordinarily tolerant with respect to natural hazards, sometimes outright indifferent. It turned out that the main factors motivating the underestimation of the effects of natural hazards were: consideration that significant are these events which occur more often than once in 2-3 years, relatively low risk of death in comparison with other kinds of hazards, and a relatively good knowledge of the origins and scope of the potential consequences of the hazards. The cases of panic are more often observed in the instances of accidents in industrial plants and of the military operations than of floods and hurricanes (Zelinsky, Kosinski, 1991). The phenomenon of the cognitive dissonance among the inhabitants of the areas of hazard consists in a greater tolerance with respect to potential hazards in the situation when essential material benefits accrue from the same place. In case of frequent appearance of the extreme phenomena of low intensity the so-called catastrophe culture may take shape. Hazards are treated then as constant inconvenience, and this can bring catastrophic consequences during the major natural disaster.

Certain social indifference characterises equally the potential victims and the decision-makers responsible for prevention. The problems of natural hazards are not especially popular among the politicians, though these problems can be cited in the attempts of justifying the failures of some economic policies, or when the opposition wants to demonstrate the incapacity of the governing administration (like in Poland after the flood of 1997). Politicians treat as important the current socio-economic problems, and not the incidental hazards. They are more interested only in those hazards, which cause bigger numbers of deaths. Political and economic costs of prevention programmes are often evaluated as disproportionately high in relation to the advantages that can be brought about by the potential reduction of losses. In 
Poland about twelve thousand population live in the areas highly vulnerable to flooding. The total costs of resettlement and other effective preventive measures are evaluated at $40-90 \%$ of the total direct flood losses through the period of 30 years. In the highly developed countries the long-term material effects of some natural disasters (i.e. after 10 years) are little visible even on a local scale and do not influence in an essential manner the development trends to date in a given community. This additionally reduces the rank of this type of hazards in the public opinion.

\section{LACK OF MEANS AND OF POLITICAL WILL TO ACT}

In the less developed countries the increased vulnerability to damage bearing results from the lack of means for the protection measures and from treatment of this problem, persistently or periodically, as a marginal one in the hierarchy of current goals of the social and economic policy of the state, like in the course of the radical transformations of the socio-economic structures. The increased vulnerability to natural disasters characterises poor rural communities, marginalised ones, and those conducting economic activities especially vulnerable to changes in the environment. The spontaneously introduced new methods of carrying out economic activities may turn out inconsistent with the local natural and/or social conditions. Local population has no influence on the undertaking of the common prevention and compensation programmes, and their poverty makes undertaking of individual measures impossible, forcing sometimes to settle in the areas often subject to hazard.

One of the reproaches with respect to the programme of the International Decade for Natural Disasters Reduction (1990-1999) was excessive promotion of the collective prevention systems, pervaded by modern technology, and of the need of transferring these systems to the less developed countries, as if overlooking the need of dealing away there, first, with the question of satisfaction of the very elementary needs. The international assistance provided can confirm the conviction of the own helplessness in the face of the hazard. In the extreme cases this external help deepens the poverty of the direct victims of the natural disaster, because the foreign financial means, intended for the victims, are being seized by the bureaucratic central and local administration institutions.

The increased vulnerability to natural disasters may appear in the period of the socio-economic transformation in the middle developed countries. Transformation, namely, consists in introduction of new technologies, directions of economic activity, social organisation, and behaviour patterns. The process of accelerated industrialisation or restructuring of the economy inclines to reduce the expenses for the preventive measures, while, at the same time, the adaptations to the hazard, valid to date, lose their effectiveness. Development of the new ones is made difficult due to concentration of 
the efforts of individuals and social institutions on adaptation to functioning in new socio-economic structures. These circumstances increase the vulnerability to natural hazards (e.g. flood of 1997). Thus, for instance, an inspection demonstrated that after 1993 in Poland the recommended work aiming at adaptation of the structures of flood protection to the new structures of public administration, and of the respective legal regulations to the new systemic conditions, was not undertaken. Likewise, decisions were not made on the methods and forms ensuring each year the availability of financial means for flood protection. Since 1994 there has even been a relative decrease of investment outlays on water management, having a direct influence on the condition of flood protection in the country (Informacja..., 1998).

\section{ACCEPTANCE OF RISK?}

The definition of the place of natural disasters in the social policies of the state constitutes another difficult challenge for the modern society. The model of safety from the period of the state-secured care is undergoing gradual erosion. This process is conditioned by the cultural, political and economic factors. At the end of the $20^{\text {th }}$ century the naive optimism of the Enlightenment as to the course of history - that the constant increase of human safety is an obvious and unavoidable fact - has been put to doubt. The abandonment of the idea of the welfare-and-care state made surface the conflict of the value of safety with another highly ranked value - freedom. It is now held that the feeling of uncertainty and risk is, and will be, a persistent characteristic in the life of individuals and communities (Beck, 1992; Zacher, 1994). Opportunities coexist with threats, and estimation of risk is no longer a problem of the state, but an everyday dilemma of every individual. In the neo-liberal perspective the idea of social solidarity should be to a greater degree replaced by the idea of individual responsibility. The feeling of threat becomes therefore a form of liberation of activity and innovative attitude, and increased effectiveness. The problem, though, consists in the fact that some threats can have a paralysing effect, while other ones may bring about indifference in periods other than of the catastrophe itself (this being the case of natural disasters).

The economic background of the contemporary transformations is constituted by the limitation of expenses from the state budget, linked in the countries of Central Europe with the trend of transferring a part of the competence of the central authorities down to the regional and local authorities, not always in company of appropriate financial capacities. High costs of the comprehensive prevention programmes and the relatively low frequency of natural hazards, especially the catastrophic ones, given the presence of numerous threats of social and technological character, puts natural disasters on a worse position as compared to other kinds of risk appearing in the less and middle developed countries (environmental degradation, crime, unemployment). 
Financial barriers force to conduct the so-called regulatory policy (Clary, 1985). In the preventive measures emphasis is put on the rigorous observation of the principles of land use, construction regulations, insurance requirements, as well as an increased share of the local communities in the preventive measures. In countries disposing of lesser means the costly preventive investments can be realised stage-wise, and the contribution of the central authorities can focus on financing the undertakings related to life saving (issuing warnings, evacuation, immediate help), which in Polish conditions is reflected through the establishment of the National Rescue and Fire-fighting System in 1995.

Water management will formally also become the task of the communal administration in Poland most probably only starting with the year 2000 . Yet, decentralisation of authority requires a better co-ordination of activity of various institutions and administrative levels. It can also indirectly contribute to amplification of the damages due to the weakness of the local authorities in enforcing the principles of land use and the construction regulations (like in Turkey in the areas affected by earthquake of 1999). Putting forward by the local authorities of the problems of hazard and the related administrative restrictions on location of activities may discourage potential external investors. The effectiveness of the regulatory policy is limited by the negative attitude of the poor local communities to participation in prevention costs. These attitudes have been largely shaped by the fact that in a not too distant past the state did compensate for even average damages. Such a situation can only be changed by making these local communities aware that the precondition for a bigger compensation is constituted by their essential contribution to the preventive measures.

Decentralisation of preventive measures down to the level of local communities and households leads to the conscious acceptance of risk by the potential victims. Awareness of risk needs more effort and time in the local communities living for decades in conditions of apparent security and lack of self-government. This fact got very sharply uncovered in the context of the pronouncement of the Polish prime minister, criticised a lot afterwards, who reproached the victims of the 1997 flood for showing carelessness in that no insurance was contracted, and hence no acceptance of risk was undertaken. Yet, even in the highly developed countries few people insure themselves against natural disasters, like in cases of the earthquake in Kobe in 1995 ( $3 \%$ of victims insured), or the Mississippi flood of 1993 (10\% of insured). The comprehensive insurance schemes against natural phenomena, without differentiation of the level of risk over the scale of the country, result in a lowered insurance premium. This concept, though, is contrary to the liberal idea of individual responsibility. Such a system was given up in Poland in 1990 for the crops and mobile assets in the rural areas, but the share of insured farmers dropped abruptly. According to Munich Reinsurance Co. only $10 \%$ of Polish households affected by flood of 1997 were insured in Silesia region ( $36 \%$ according to Polish field survey). The increase of mate- 
rial losses in some parts of south-eastern United States and the growth of costs of re-insurance borne by the insurance companies resulted even in abandonment altogether of the insurance against natural disasters. In this situation one can hardly expect in Poland a bigger interest of the population, subject to hazard, in the preventive measures, and the enforcement of a minimum protection programme with a significant (at least initially) contribution of the central authorities in its financing seem, however, indispensable.

\section{REFERENCES}

Beck U., 1992, Risk Society: Towards a New Modernity, Sage, London.

B uj a k F., 1932, Przedmowa [Foreword], [in:] A. Walawender, Kronika klęsk elementarnych w Polsce i krajach sąsiednich w latach 1450-1586 [Chronicles of calamities in Poland and the neighbouring countries in 1450-1586], Part I. Badania z dziejów spotecznych $i$ gospodarczych, 10, Lwów, III-VIII.

Cla ry B.C., 1985, The Evolution and Structure of Natural Hazard Policies, Public Administration Review, 45, 20-28.

Hewitt K., 1983, The Idea of Calamity in a Technocratic Age, [in:] K. Hewitt (ed.), Interpretations of Calamity, Allen Unwin, Boston, 3-32.

Informacja o wynikach kontroli stanu zabezpieczenia przeciwpowodziowego kraju oraz przebiegu dziatań ratowniczych w czasie powodzi na terenach potudniowejizachodniej Polski w lipcu 1997 r., 1998, [Information on the Results of Inspection of the Flood Protection Measures of the Country and the Course of the Rescue Operations during the Flood in Southern and Western Poland in July 1997], Najwyzsza Izba Kontroli.

Lis ow ski A., 1996, Antropogeniczne uwarunkowania klęsk żywiołowych [Human Preconditions of Natural Disasters], Przeglad Geograficzny, LXVIII, 1-2, 67-78.

Smith K., 1995, Environmental Hazards. Assessing Risk and Reducing Disaster, Routledge, London-New York.

Z a cher L., 1994, Socjologia ryzyka. Próba nowej subdyscypliny [Sociology of Risk. An Attempt at a New Sub-discipline], [in:] L.W. Zacher, A. Kiepas (eds), Spoteczeństwo a ryzyko, Transformacje, Warszawa, 20-42.

Zelinsky W., Kosiński L., 1991, Emergency Evacuation of Cities. A Cross-National Historical and Geographical Study, Rowman-Littlefield, Savage. 